NASA/TM-2008-215425

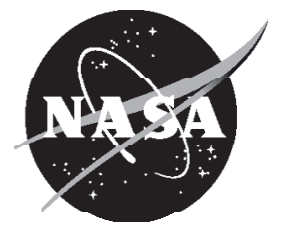

\title{
Adaptation and Re-Use of Spacecraft Power System Models for the Constellation Program
}

Jeffrey S. Hojnicki and Thomas W. Kerslake

Glenn Research Center, Cleveland, Ohio

Mark Ayres and Augustina H. Han

Hamilton Sundstrand SLS Rocketdyne, Canoga Park, California

Adrian M. Adamson

Deep Space Systems, Inc., Littleton, Colorado 


\section{NASA STI Program . . . in Profile}

Since its founding, NASA has been dedicated to the advancement of aeronautics and space science. The NASA Scientific and Technical Information (STI) program plays a key part in helping NASA maintain this important role.

The NASA STI Program operates under the auspices of the Agency Chief Information Officer. It collects, organizes, provides for archiving, and disseminates NASA's STI. The NASA STI program provides access to the NASA Aeronautics and Space Database and its public interface, the NASA Technical Reports Server, thus providing one of the largest collections of aeronautical and space science STI in the world. Results are published in both non-NASA channels and by NASA in the NASA STI Report Series, which includes the following report types:

- TECHNICAL PUBLICATION. Reports of completed research or a major significant phase of research that present the results of NASA programs and include extensive data or theoretical analysis. Includes compilations of significant scientific and technical data and information deemed to be of continuing reference value. NASA counterpart of peer-reviewed formal professional papers but has less stringent limitations on manuscript length and extent of graphic presentations.

- TECHNICAL MEMORANDUM. Scientific and technical findings that are preliminary or of specialized interest, e.g., quick release reports, working papers, and bibliographies that contain minimal annotation. Does not contain extensive analysis.

- CONTRACTOR REPORT. Scientific and technical findings by NASA-sponsored contractors and grantees.

- CONFERENCE PUBLICATION. Collected papers from scientific and technical conferences, symposia, seminars, or other meetings sponsored or cosponsored by NASA.

- SPECIAL PUBLICATION. Scientific, technical, or historical information from NASA programs, projects, and missions, often concerned with subjects having substantial public interest.

- TECHNICAL TRANSLATION. Englishlanguage translations of foreign scientific and technical material pertinent to NASA's mission.

Specialized services also include creating custom thesauri, building customized databases, organizing and publishing research results.

For more information about the NASA STI program, see the following:

- Access the NASA STI program home page at http://www.sti.nasa.gov

- E-mail your question via the Internet to help@ sti.nasa.gov

- Fax your question to the NASA STI Help Desk at 301-621-0134

- Telephone the NASA STI Help Desk at 301-621-0390

- Write to: NASA Center for AeroSpace Information (CASI) 7115 Standard Drive Hanover, MD 21076-1320 
NASA/TM-2008-215425

AIAA-2008-5616

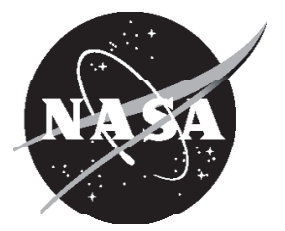

\title{
Adaptation and Re-Use of Spacecraft Power System Models for the Constellation Program
}

\author{
Jeffrey S. Hojnicki and Thomas W. Kerslake \\ Glenn Research Center, Cleveland, Ohio \\ Mark Ayres and Augustina H. Han \\ Hamilton Sundstrand SLS Rocketdyne, Canoga Park, California \\ Adrian M. Adamson \\ Deep Space Systems, Inc., Littleton, Colorado
}

Prepared for the

Sixth International Energy Conversion Engineering Conference (IECEC)

sponsored by the American Institute of Aeronautics and Astronautics

Cleveland, Ohio, July 28-30, 2008

National Aeronautics and

Space Administration

Glenn Research Center

Cleveland, Ohio 44135 
This report contains preliminary findings, subject to revision as analysis proceeds.

Trade names and trademarks are used in this report for identification only. Their usage does not constitute an official endorsement, either expressed or implied, by the National Aeronautics and Space Administration.

Level of Review: This material has been technically reviewed by technical management.

Available from

NASA Center for Aerospace Information 7115 Standard Drive

Hanover, MD 21076-1320
National Technical Information Service 5285 Port Royal Road Springfield, VA 22161

Available electronically at http://gltrs.grc.nasa.gov 


\title{
Adaptation and Re-Use of Spacecraft Power System Models for the Constellation Program
}

\author{
Jeffrey S. Hojnicki and Thomas W. Kerslake \\ National Aeronautics and Space Administration \\ Glenn Research Center \\ Cleveland, Ohio 44135 \\ Mark Ayres and Augustina H. Han \\ Hamilton Sundstrand SLS Rocketdyne \\ Canoga Park, California 91309 \\ Adrian M. Adamson \\ Deep Space Systems, Inc. \\ Littleton, Colorado 80128
}

\begin{abstract}
NASA's Constellation Program is embarking on a new era of space exploration, returning to the Moon and beyond. The Constellation architecture will consist of a number of new spacecraft elements, including the Orion crew exploration vehicle, the Altair lunar lander, and the Ares family of launch vehicles. Each of these new spacecraft elements will need an electric power system, and those power systems will need to be designed to fulfill unique mission objectives and to survive the unique environments encountered on a lunar exploration mission. As with any new spacecraft power system development, preliminary design work will rely heavily on analysis to select the proper power technologies, size the power system components, and predict the system performance throughout the required mission profile. Constellation projects have the advantage of leveraging power system modeling developments from other recent programs such as the International Space Station (ISS) and the Mars Exploration Program. These programs have developed mature power system modeling tools, which can be quickly modified to meet the unique needs of Constellation, and thus provide a rapid capability for detailed power system modeling that otherwise would not exist.
\end{abstract}

\section{Nomenclature}
A-hr ampere-hours
kWe kilowatts electric
Vdc volts, direct current
W-hr watt-hours
$\beta \quad$ solar beta angle

\section{Introduction}

The Constellation architecture will consist of a number of new spacecraft elements, including the Orion crew exploration vehicle, the Altair lunar lander, the Ares family of launch vehicles and destination surface systems, i.e., lunar outpost. Each of these spacecraft elements, shown in figure 1, will need an electric power system (EPS), and those power systems will need to be designed to fulfill unique mission objectives and to survive the unique environments encountered on a lunar exploration mission. All spacecraft require an EPS, to provide the power required by spacecraft systems and, in the case of 


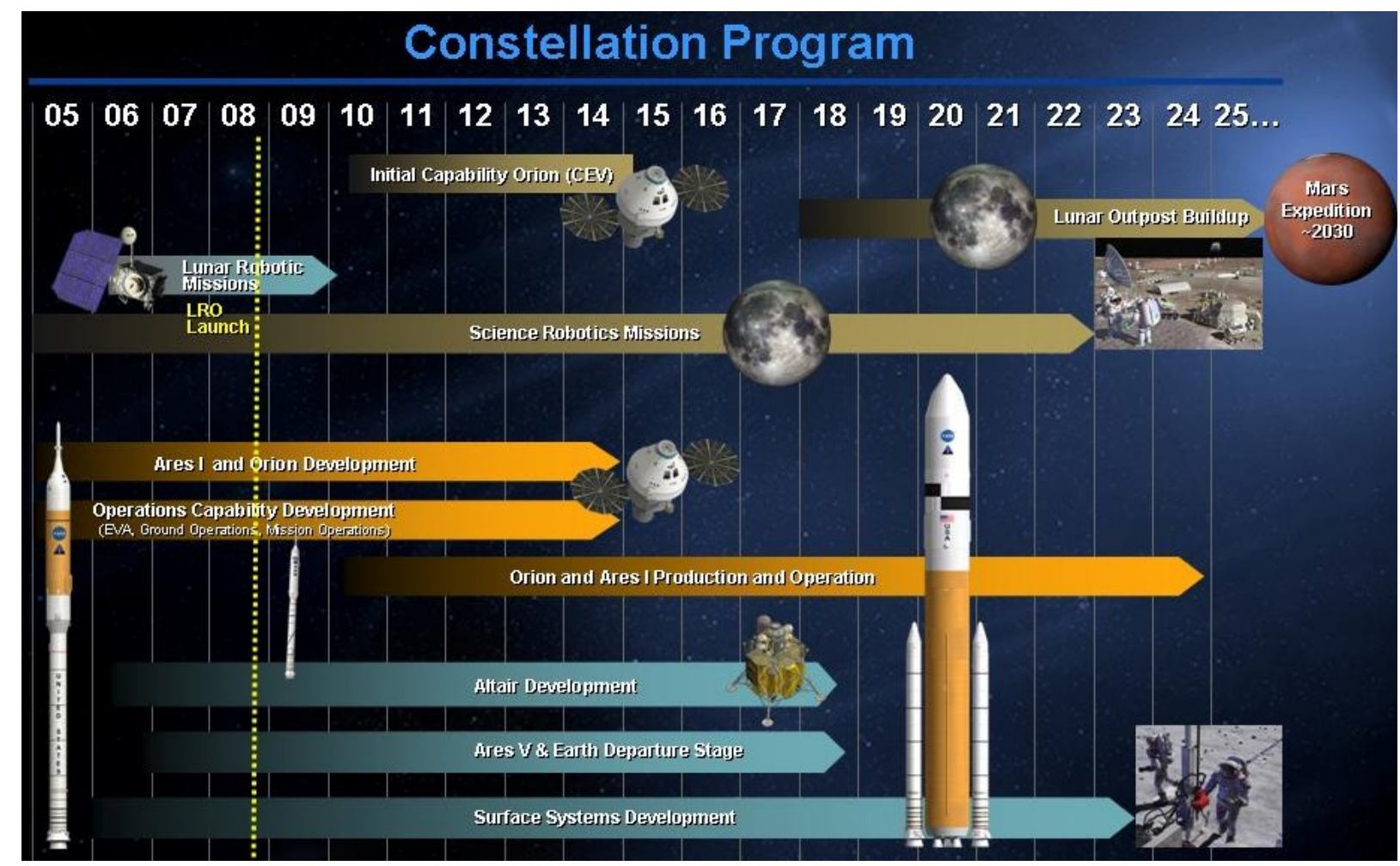

Figure 1.-Constellation Program timeline.

Constellation, the crewmembers on-board. Typical of any new spacecraft EPS development, preliminary design work relies heavily on analysis to select the proper power technologies, size the power system components, and verify that the system performance will meet the requirements of the mission. Traditionally, many projects choose to build new power system models from scratch, since there are no industry-standard tools to model the performance of spacecraft power systems. Projects within NASA's Constellation Program, though, have the advantage of leveraging power system modeling developments from other recent programs, such as the International Space Station (ISS) and the Mars Exploration Program. These programs have developed mature power system modeling tools, unique to their needs, that were validated against ground and in-space test data. The ISS program uses two models that are of particular interest: the System Power Analysis for Capability Evaluation (SPACE) model developed at the NASA Glenn Research Center, and the Electric Power Simulation (EPSIM) model developed by Hamilton Sundstrand SLS, Rocketdyne. SPACE has been used extensively to predict how the ISS power system will perform under a wide variety of on-orbit conditions, environments and constraints. Via validation against ISS telemetry, SPACE has been demonstrated to predict currents, voltages and temperatures throughout the EPS within 5 percent of actual performance.

All spacecraft require an EPS, to provide the power required by spacecraft systems and, in the case of Constellation, the crewmembers on-board. Typical of any new spacecraft EPS development, preliminary design work relies heavily on analysis to select the proper power technologies, size the power system components, and verify that the system performance will meet the requirements of the mission. Traditionally, many projects choose to build new power system models from scratch, since there are no industry-standard tools to model the performance of spacecraft power systems. Projects within NASA's Constellation Program, though, have the advantage of leveraging power system modeling developments from other recent programs, such as the International Space Station (ISS) and the Mars Exploration Program. These programs have developed mature power system modeling tools, unique to their needs, that were validated against ground and in-space test data. The ISS program uses two models that are of 
particular interest: the System Power Analysis for Capability Evaluation (SPACE) model developed at the NASA Glenn Research Center, and the Electric Power Simulation (EPSIM) model developed by Hamilton Sundstrand SLS, Rocketdyne. SPACE has been used extensively to predict how the ISS power system will perform under a wide variety of on-orbit conditions, environments and constraints. Via validation against ISS telemetry, SPACE has been demonstrated to predict currents, voltages and temperatures throughout the EPS within 5 percent of actual performance.

EPSIM, has been used during the design, testing and operational phase of the ISS. It is presently being used in the ISS Space Station Training Facility (SSTF) to model the power system and its associated thermal control system. EPSIM has evolved extensive fault simulation capability to support astronaut and flight controller training for off-nominal conditions.

The Mars Exploration Rover (MER) program performed comprehensive lithium-ion (Li-Ion) battery characterization testing to develop an empirical battery model. Flight operation validated the accuracy of this model over a wide range of operating conditions. Similarly, solar array performance algorithms were validated in-flight, along with a tool for load timeline definition.

Still, none of these models can be applied out-of-the-box to the Constellation program, as they were built to meet the specific needs of their programs. The Constellation program seeks to return to the moon, at which exist very different space environments than in low Earth orbit or at Mars. Those differing space environments, such as thermal and radiation, must be added into the models. Also, since the power system components have not yet been designed and tested for the new spacecraft, their performance must be estimated analytically. The possibility of modeling errors is significant without test data against which to vet model results.

This paper describes the process being implemented to make optimum re-use of existing, validated models for Constellation spacecraft, specifically focusing on the most near-term element, the Orion crew exploration vehicle. The unique aspects of the lunar mission that must be implemented in the models is described, and it will be shown that comparison of results from the three different models can serve as one method of validating model predictions before actual test data are available.

\section{Constellation Requirements}

Table I shows the key mission and vehicle power system design requirements for each Constellation element. Candidate power technologies envisioned to meet these requirements are also summarized.

TABLE I.-KEY CONSTELLATION POWER SYSTEM DESIGN AND MISSION REQUIREMENTS AND TECHNOLOGIES ${ }^{\mathrm{a}}$

\begin{tabular}{|c|c|c|c|c|c|c|}
\hline Element & $\begin{array}{c}\text { First } \\
\text { mission } \\
\text { date }\end{array}$ & $\begin{array}{l}\text { Key mission environments and } \\
\text { durations }\end{array}$ & $\begin{array}{l}\text { Reusability and } \\
\text { other unique } \\
\text { requirements }\end{array}$ & $\begin{array}{c}\text { Power level } \\
\text { estimate, } \\
\mathrm{kWe}\end{array}$ & $\begin{array}{l}\text { Power system } \\
\text { architecture } \\
\text { and voltage } \\
\end{array}$ & $\begin{array}{l}\text { Power technology } \\
\text { candidates }\end{array}$ \\
\hline $\begin{array}{l}\text { Ares-1 } \\
\text { First Stage }\end{array}$ & \multirow[t]{3}{*}{$\sim 2015$} & Earth ascent (min) & Reusable & $\sim 4.0$ & $\begin{array}{l}\text { Channelized, } \\
\text { unregulated } \\
28-V d c\end{array}$ & $\begin{array}{l}55 \text { A-hr, silver zinc } \\
\text { batteries }\end{array}$ \\
\hline $\begin{array}{l}\text { Ares-1 } \\
\text { Upper Stage }\end{array}$ & & Earth ascent (min) & $* * *$ & $\begin{array}{l}\sim 2.0 \\
\text { instrument } \\
\sim 7.0 \text { skirt } \\
\end{array}$ & $\begin{array}{l}\text { Channelized, } \\
\text { unregulated } \\
28-\text { Vdc buses }\end{array}$ & $\begin{array}{l}12 \text { and } 24 \text { A-hr, } \\
\text { Primary Lithium-ion } \\
\text { batteries }\end{array}$ \\
\hline $\begin{array}{l}\text { Orion Service } \\
\text { Module (SM) }\end{array}$ & & $\begin{array}{l}\text { Earth ascent (min), } \\
\text { Low Earth Orbit (216 days), } \\
\text { Trans-lunar Injection Burn (min), } \\
\text { Cis-lunar space ( } 8 \text { days), } \\
\text { Low Lunar Orbit (210 days) }\end{array}$ & $\begin{array}{l}\text { SM must operate } \\
\text { post-separation } \\
\text { from the CM for } \\
\text { Earth orbit reentry } \\
\text { disposal }\end{array}$ & $\sim 1.0$ & $\begin{array}{l}\text { Channelized, } \\
\text { unregulated } 27 \\
\text { to } 36 \text { Vdc at } \\
\text { Interface } 1 \\
\text { between } \\
\text { Constellation } \\
\text { Elements (ref. 1) }\end{array}$ & $\begin{array}{l}\text { UltraFlex solar array } \\
\text { wings with state of } \\
\text { the art triple junction } \\
\text { photovoltaic cells } \\
\\
55 \text { A-hr, secondary } \\
\text { Lithium-ion batteries }\end{array}$ \\
\hline
\end{tabular}




\begin{tabular}{|c|c|c|c|c|c|c|}
\hline \begin{tabular}{|l|} 
Orion Crew \\
Module $(\mathrm{CM})$
\end{tabular} & & $\begin{array}{l}\text { Above items, plus: } \\
\text { Earth Reentry (min), } \\
\text { Post-landing on land or } \\
\text { ocean ( } 36 \mathrm{hr})\end{array}$ & $\begin{array}{l}\text { Potential for CM } \\
\text { reuse after land } \\
\text { landing, } \\
1.5 \mathrm{kWe} \text { power } \\
\text { transfer to Altair }\end{array}$ & $\sim 3.5$ & $\begin{array}{l}\text { Channelized, } \\
\text { unregulated } 23 \\
\text { to } 36 \text { Vdc at } \\
\text { Interface } 2 \\
\text { (CM loads) } \\
\text { (ref. 1) }\end{array}$ & $\begin{array}{l}\text { 55 A-hr, secondary } \\
\text { Lithium-ion batteries }\end{array}$ \\
\hline $\begin{array}{l}\text { Ares-V } \\
\text { First Stage }\end{array}$ & \multirow[t]{5}{*}{$\sim 2020$} & Earth ascent (min) & Reusable & $\begin{array}{l}<\sim 100 \text { per } \\
\text { booster }\end{array}$ & $\begin{array}{l}\text { Channelized, } \\
\text { unregulated } \\
220-V d c\end{array}$ & $\begin{array}{l}270 \text { Vdc Lithium-ion } \\
\text { batteries }\end{array}$ \\
\hline $\begin{array}{l}\text { Ares-V } \\
\text { Core Stage }\end{array}$ & & Earth ascent (min) & $* * *$ & $\sim 10$ & $\begin{array}{l}\text { Channelized, } \\
\text { unregulated } \\
28-\text { Vdc }\end{array}$ & $\begin{array}{l}\text { Primary Lithium-ion } \\
\text { batteries }\end{array}$ \\
\hline \begin{tabular}{|l|} 
Ares-V Earth \\
Departure \\
Stage
\end{tabular} & & $\begin{array}{l}\text { Earth ascent (min), } \\
\text { Low Earth Orbit }(<4 \text { days), } \\
\text { Trans-lunar Injection Burn (min) }\end{array}$ & $\begin{array}{l}1.5 \mathrm{kWe} \text { power } \\
\text { transfer to Altair }\end{array}$ & \begin{tabular}{|l|} 
4.5 \\
including \\
Altair Power \\
Transfer \\
\end{tabular} & $\begin{array}{l}\text { Channelized, } \\
\text { unregulated } \\
28-\text { Vdc }\end{array}$ & Primary fuel cell \\
\hline $\begin{array}{l}\text { Altair Lander } \\
\text { Descent Stage }\end{array}$ & & $\begin{array}{l}\text { Earth ascent (min), } \\
\text { Low Earth Orbit (<4 days), } \\
\text { Trans-lunar Injection Burn (min), } \\
\text { Cis-lunar space }(4 \text { days), } \\
\text { Low Lunar Orbit ( } 1 \text { day), } \\
\text { Lunar descent (min), } \\
\text { Lunar surface (10 days) } \\
\end{array}$ & $\begin{array}{l}\text { Potential reuse for } \\
\text { lunar outpost }\end{array}$ & $\sim 5$ & $\begin{array}{l}\text { Channelized, } \\
\text { unregulated } \\
28-V d c\end{array}$ & Primary fuel cell \\
\hline $\begin{array}{l}\text { Altair Lander } \\
\text { Ascent Stage }\end{array}$ & & $\begin{array}{l}\text { Above items, } \\
\text { Plus Lunar ascent }(2 \mathrm{hr})\end{array}$ & $* * *$ & $\sim 1.5$ & $\begin{array}{l}\text { Channelized, } \\
\text { unregulated } \\
28-V d c \\
\end{array}$ & $\begin{array}{l}\mathrm{LiMnO}_{2} \text { Primary } \\
\text { Lithium-ion Battery }\end{array}$ \\
\hline Lunar Outpost & $\sim 2022$ & $\begin{array}{l}\text { Lunar surface (South Pole, } \\
\text { Shackleton Crater Rim) }(10 \mathrm{yr}) \text {, } \\
\text { Complex solar lighting profile } \\
\text { through lunation }\end{array}$ & \begin{tabular}{|l} 
Support \\
continuous 6- \\
month crewed \\
missions, RFC \\
reactants possibly \\
from lander \\
propellant tank \\
scavenging
\end{tabular} & $\begin{array}{l}\text { Up to } \sim 40 \\
\text { (day time) }\end{array}$ & $\begin{array}{l}\text { Channelized, } \\
\text { regulated } \\
270-V d c \\
\text { primary, } \\
\text { regulated } \\
28-V d c \\
\text { secondary }\end{array}$ & $\begin{array}{l}\text { Advanced solar array } \\
\text { wings or modified } \\
\text { Orion Ultraflex } \\
\text { wings with advanced } \\
\text { multi-junction } \\
\text { photovoltaic cells, } \\
\text { PEM Regenerative } \\
\text { Fuel Cells (RFCs); } \\
\text { Fission Power } \\
\text { (option) }\end{array}$ \\
\hline
\end{tabular}

${ }^{\mathrm{a}}$ Note that table I does not include Constellation Extravehicular Activity (EVA) suit power system development.

Two of the elements, the Orion Crew Exploration Vehicle and the Lunar Outpost, envision using solar array and battery systems, which are amenable to assessment with the heritage power system models. The Orion power system will break new ground in several key aspects: (1) the first in-space flight operations of an UltraFlex solar array wing (the Phoenix UltraFlex wings were not deployed until after landing on the Mars surface); (2) the first solar array to operate in each of the following unique environments: low Earth orbit (LEO), cis-lunar space, low lunar orbit (LLO) and then cis-lunar space back to Earth; (3) the first solar array wing in U.S. human spaceflight history providing flight-critical power to prevent loss-of-crew; (4) the first solar array wing known to be designed for 3-g class deployed loading; and (5) first use of lithium-ion batteries in the power system for a crewed spacecraft.

A solar power system at the Shackleton Crater rim lunar outpost will experience a complex sun lighting environment (ref. 2) during local winter when the sun moves azimuthally low on the horizon. This environment creates dozens of short-lived, sun/shade periods during the course of a single 30 day lunation over which the outpost power system must maintain an energy balance. Many of these Constellation elements are integrated during flight, e.g., the Orion and Altair. As such, interface requirement documents and a "level 2" interface power quality specification (ref. 1) have been prepared to manage element interfaces. More information about Constellation power systems can be found in the literature (ref. 3). 


\section{EPS Modeling Heritage}

Since every spacecraft requires an electric power system, EPS models have been used to predict the performance of spacecraft for decades. Often, those models are built from scratch to support the specific spacecraft, since there are no industry standard tools for space-based power system modeling, and since the power technology, environments and/or mission requirements can vary greatly from project to project. New models take time to develop and validate, however, and it is a great benefit to a project to have a detailed power system model available early in the project design cycle. Constellation is leveraging past model development to bring detailed models on-line quickly.

\section{International Space Station}

The International Space Station's EPS is unique in its size and scope. It is currently the largest EPS ever flown in space, and is still growing. Soon it will produce nearly $100 \mathrm{kWe}$ of power. Since the entire EPS could never have be assembled and tested on the ground in an integrated fashion, system-level EPS assessments have been critical to the design, development and verification of the EPS. These assessments have been, and continue to be, performed entirely by analysis. Legacy power models were not sufficient for ISS, since they lacked the detail and scope needed to model the ISS. Several EPS models were developed for the ISS program for different purposes. Two models in particular, have been deemed useful for adaptation for the Constellation Program.

\section{SPACE}

System Power Analysis for Capability Evaluation (SPACE) (ref. 4) is a model developed at the NASA Glenn Research Center that has been one of the pivotal tools used to support the design, development and operation of the ISS. SPACE is a uniquely integrated power system model, incorporating a variety of modules tied together with integration/optimization routines and graphical output. The modules include orbit mechanics, solar array pointing, shadowing, thermal, and electrical performance, battery performance, and power management and distribution (PMAD) performance.

SPACE supported the ISS design phase, which required the model to predict the amount of power available for a given system configuration, spacecraft orientation, solar array pointing condition, orbit, etc. In this source-driven mode, the model must assure that energy balance is achieved-meaning that energy removed from the batteries must be restored (or balanced) each and every orbit. Alternatively, SPACE can be used in a load-driven mode to support spacecraft operations. In this mode, SPACE determines whether a given distributed, time-varying electrical load profile can be supported by the power system and determines whether the system stays in energy balance, and whether or not any system limits (voltage/current trip settings, etc.) are exceeded. This load-driven mode is used to assess each Shuttle mission to ISS, in support of the Certification of Flight Readiness (CoFR) process.

The first version of SPACE was released in 1989. Since then, SPACE development has progressed to the current version (3.3) which has been thoroughly validated against on-orbit telemetry (ref. 5) and remains in daily use to support the ISS program and its partners.

Because of the complex, articulating geometry of the ISS, shadowing onto solar arrays from other station structures is a significant issue, and so SPACE contains an integrated shadowing model. Most EPS models do not require a shadowing module, since most spacecraft are small, and are designed to fly in attitudes that minimize or eliminate shadowing. The Orion spacecraft, however, will be visiting the ISS, and thus, its solar arrays will experience similar shadowing to the ISS wings. Therefore, having a model with an integrated shadowing capability available is very useful to Orion. 


\section{EPSIM}

Electric Power Simulation (EPSIM) originated out of an effort by the Glenn Research Center and Rocketdyne in 1989 to utilize electric utility software tools in the design and analysis of the Space Station Electric Power System. A commercial software product, HABITAT, was procured. This software is used to build control centers for electric utilities. It is sufficiently general in its design that it allows entirely new applications to be constructed. This was important for the Space Station because many of its subsystems are not electric utility applications. In order to model the behavior of the electric system, the effects of other systems, such as orbital mechanics, thermal, fluid/hydraulic, mechanical and structural systems need to be considered.

The power system simulation model originally constructed in EPSIM was used to support prototyping of electric power system control algorithms for requirements generation. These prototype algorithms were run in the simulation to judge their performance and provide feedback to the requirements engineers. Over time the simulation was upgraded to include more fidelity and evolved into a time-domain simulation of the electrical, orbital, thermal, fluid, structural and mechanical subsystems of the Space Station. Specialized sparse non-linear equation solvers were adopted from the electrical utility industry to solve, in real-time, the differential/algebraic equations used to model those subsystems and their coupled behavior (ref. 6).

As the design of the Space Station progressed and requirements were translated into product code, the need arose for simulations to test that code before it was delivered to the laboratories and used with real hardware. The software test plans for the Space Station included the development of comprehensive realtime tool suites to meet that need. However the EPS software schedule was accelerated ahead of the delivery of the system tools and Rocketdyne needed an interim solution for software test and decided to use EPSIM. Rocketdyne was able to leverage the graphics, scripting and real-time tools provided by HABITAT for software test. Specialized device drivers were written enabling EPSIM to communicate with the Mil-Std-1553 cards used by the Flight Software to control the EPS system.

The engineers at the Space Station Training Facility (SSTF) were challenged by the large number of models which they had to develop to support the training of the astronauts and flight controllers. They decided to look at the models developed elsewhere on the Space Station to see if they could be leveraged for use in the SSTF - thereby saving significant time and effort. After visiting Rocketdyne they decided to use EPSIM as the EPS model in the SSTF. That is the role that EPSIM is presently filling on the ISS.

\section{Mars Exploration Program}

The Mars Exploration Rover (MER) program operates two rovers on the surface of Mars near Mars' equator, at Meridiani Planum and Gusev Crater. Originally designed for a 90 day primary mission, the rovers have been returning science data for 4 years and 4 months, as of May 2008. Electrical power is the primary operating constraint for the rovers, which have $1.3 \mathrm{~m}^{2}$ of active solar cell area subject to up to 60 percent loss from dust. A detailed and flexible tool for modeling the load timeline was used during spacecraft development to plan each W-hr of consumption in a variety of spacecraft configurations. The MER system power analysis tool modeled the cruise phase, which used the rovers' Li-Ion batteries and a cruise stage solar array; the entry descent and landing (EDL) phase, in which $\mathrm{Li}-\mathrm{SO}_{2}$ primary landing batteries supplemented by thermal batteries provided most of the power; and the landed operation phase, powered by the rovers' solar arrays and Li-ion batteries. The power load database and timeline generation tool used during MER's development saw some use in operations as a means of performing quick-

turnaround analysis, and part of it fed into the MER operational planning tool, APGEN. The load timeline analysis tool has been modified and extended for use on Orion. 
As the MER rovers were the first planetary exploration program to use Li-Ion batteries, the program performed a comprehensive battery test program to provide a large volume of characterization data for an empirical battery model used during development and in operations. The MER rover batteries operate over a temperature range spanning from approximately $-20^{\circ} \mathrm{C}$ to $30^{\circ} \mathrm{C}$, and the entire range was characterized in the battery test program. Special discharge profiles provided extra information characterizing the behavior at low charge and discharge rates. The result is a battery model that has been proven to model the MER batteries with typical voltage prediction within $0.1 \mathrm{~V}$ over a wide range of temperature, state of charge, and charge rate. This model is still in use in MER operations, modified to account for the effect of long-life degradation.

\section{Adapting Heritage Models for Constellation}

\section{Updating Existing Models}

\section{Mission Timelines}

The load timeline development tool used on MER has been directly applicable for Orion. As shown in figure 2, it consists of several parts: The Power Equipment List (PEL) is a database of the voltagedependent load characteristics of each functional load. The subset definition database is used as a filter to select load subsets of interest for reporting load subtotals. This feature is used to track power consumption by subsystem, spacecraft module, current sensor, and thermal node, among others. The mode definition database is used to define groups of load states that correspond to different spacecraft configurations, for easier input into the analysis. The load state timeline defines the load state changes as a function of time. State transitions of individual items as well as mode changes are captured here. The state history worksheet stores the state of every power consuming item on the spacecraft, at every time step in which there is a load transition.

The load timeline tools are combined into a system power analysis workbook, which is hosted in Microsoft Excel (Microsoft Corporation) for easy collaboration among the teammates, and is used by Orion with little modification. The system power analysis workbook was extended by Orion to include a bus voltage solver based on I-V curves.

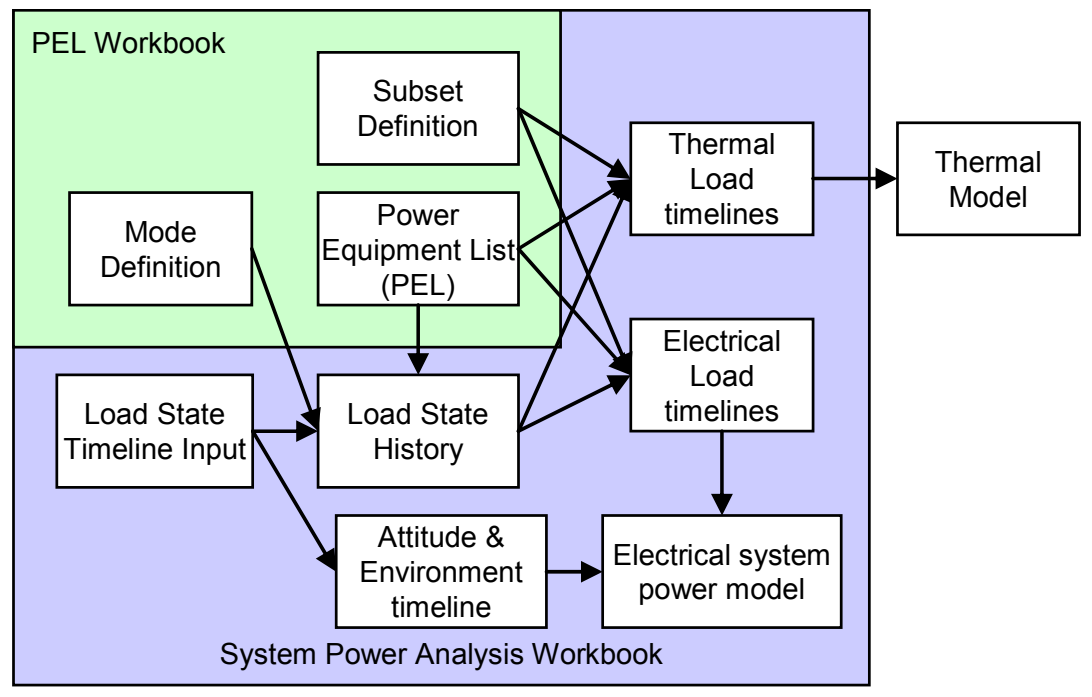

Figure 2.-Timeline development tool flow. 


\section{Environments}

Neither the ISS nor the Mars power system models were originally designed for a lunar mission, so adding the appropriate lunar orbit environment was a key required enhancement in order to model the Orion power system. Although, compared to Earth or Mars orbits, most of the spacecraft environmental parameters (radiation, micrometeoroid, plasma, etc.) differ at the Moon; it is the orbital thermal environment that is most unique and most important for power system models. Solar array performance is a strong function of temperature, with performance typically decreasing with increased temperature. The lunar surface is highly emitting (emissivity $>0.9$ ) and thus an orbiting spacecraft experiences a very large infra-red heat flux from the surface during orbits with low solar $\beta$ angles. Fluxes greater than $1200 \mathrm{~W} / \mathrm{m}^{2}$ are possible, which can result in solar array temperatures exceeding $100{ }^{\circ} \mathrm{C}$. Thus the models had to be updated to properly predict the thermal interactions with the lunar surface.

Orion also is designed for LEO missions to the ISS, and will spend up to 4 days loitering in LEO prior to injection onto a trans-lunar trajectory for lunar missions. Therefore, power system models must be able to predict the solar array temperature and performance in all three environments: LEO, cis-lunar space, and LLO; and should be able to transition seamlessly between the various environments within one analysis, in order to predict the performance over the entire mission timeline.

\section{Solar Array}

Heritage solar array models include those for the LEO ISS solar array wing (SAW) incorporated into SPACE and EPSIM. The ISS SAW has flexible panel blankets populated with silicon solar cells, operates at $160 \mathrm{Vdc}$ and employs one silicon by-pass diode for each group of 8 series connected solar cells. By contrast, the UltraFlex wing, for Orion and lunar surface applications, is comprised of open-weave mesh gores populated with state-of-the-art triple junction solar cells and operates at low voltage $(32 \mathrm{Vdc})$. Each solar cell has a by-pass diode and solar cell strings are paralleled together to form higher current level electrical segments. For launch, the gores are fan-folded between rigid panels with solar cell protection provided by foam strips bonded to the gore back side.

Solar array electrical performance model updates for Constellation Program applications include revised power harnessing voltage drop, revised gore/solar cell thermal model, revised solar cell current response to planetary albedo and Earth umbral illumination, discrete silicon or monolithic gallium-arsenide (GaAs) bypass diode voltage drop, and several revised performance loss factors.

ISS wing strings are routed to the sequential shunt unit regulator and string pairs share common returns. For Constellation UltraFlex wing applications, the low operating voltage leads to hundreds of solar cell strings that must paralleled into higher current electrical segments more practical for harness design. Models were updated for the UltraFlex wing to calculate separate resistive voltage drops for the low current string wiring and high current segment harnessing routed back to the solar array switch module.

The ISS solar cell thermal model is comprised of 3 nodes to account for front and back surface radiant boundary condition and conduction paths between the solar cell and panel. For Constellation UltraFlex modeling, the solar cell must be modeled with 4 nodes to account for conduction paths and radiant boundary conditions. Unlike the ISS thermal model, the UltraFlex solar cell front nodes must be modeled to receive front side and backside radiant boundary conditions due to the open-weave mesh substrate that exposes the solar cell backside.

ISS silicon cells have less spectral performance sensitivity compared with Constellation mission triple junction cells with each sub-cell spectral response carefully controlled to produce equal current under the Air Mass Zero (AM0) solar spectrum. As such, planetary albedo illumination current production must be modeled using light intensity and spectrum corrections factors. The Earth or Moon spectral albedo correction factor is calculated by integrating the solar spectrum with the planetary spectral albedo and the solar cell spectral response. Earth albedo is spectrally similar to solar illumination and hence provides a correction factor of 1. Lunar albedo spectrum is blue depleted and leads to a correction factor of 0.625 (due to top junction current limiting). For Orion lunar outpost missions or lunar surface missions, UltraFlex solar arrays will experience multi-hour long lunar eclipse lighting as the Moon transits the Earth's penumbra and umbra. Earth's penumbra 
is modeled as AM0 illumination that varies from 1 Sun to 0.017 Suns. Umbral illumination is red-biased (highly refracted through Earth's atmosphere) and results in a spectral correction factor of 0.022 . This low intensity, red umbral lighting results in essentially no current production from triple junction solar cells.

The solar cell string current-voltage (IV) curve under shadowing conditions is calculated based on the contribution of unshadowed and shadowed solar cells. The latter contributes a voltage drop from the active by-pass diode that is modeled as a $0.7 \mathrm{~V}$ drop for silicon diodes and as a $1.7 \mathrm{~V}$ drop for an epitaxially grown GaAs monolithic diode. Shadowed wing current loss is larger for solar cell strings with monolithic by-pass diodes with greater voltage drop compared to those with silicon diodes. Wing current loss factors were calculated for Constellation UltraFlex wing spar self-shadowing as a function of sun offpointing angle. Using geometric modeling, solar cell shadow fractions were calculated to determine the shadowed IV curve for each solar cell string and the resulting current loss at the string nominal operating voltage. Industry standard solar cell equivalent radiation dose calculation models (refs. 7 to 9) were run for the Constellation UltraFlex wing application in LEO mated with ISS (trapped electron and proton environments) and in LLO for lunar outpost missions (solar flare proton environment). Results showed that the LLO solar flare proton environment led to the higher value of equivalent dose compared to the ISS LEO trapped radiation environment. For Constellation UltraFlex lunar surface applications, lunar dust coverage is a degradation mechanism that must be modeled. Solar cell current loss is modeled using empirical data for current output versus dust areal mass loading (ref. 10). Lastly, because Constellation UltraFlex wings must safely operate beyond LEO in a sparse space plasma environment, the risk of differential charging and damaging electrostatic discharges (ESD) is high. To redress this ESD risk, solar cell coverglasses will incorporate a weakly conducting coating to bleed off charge. However, this coating changes the coverglass spectral transmittance and hence, the solar cell IV performance. Conductively coated coverglass spectral transmittance curves were obtained and convolved with the bare solar cell spectral response to calculate the glassing current and voltage loss factors under AM0 illumination.

\section{Batteries}

The Li-Ion battery model used for Orion is based on a comprehensive set of characterization data from the Mars Exploration Rover program, scaled for the larger Orion batteries. The original data (ref. 11) are shown in figure 3, with voltage as a function of charge rate, state of charge, and temperature (color).

In each charge cycle (positive charge rate), the battery was charged at a constant current until the voltage reached $4.1 \mathrm{~V}$, at which point the voltage was held constant and the charge rate was allowed to

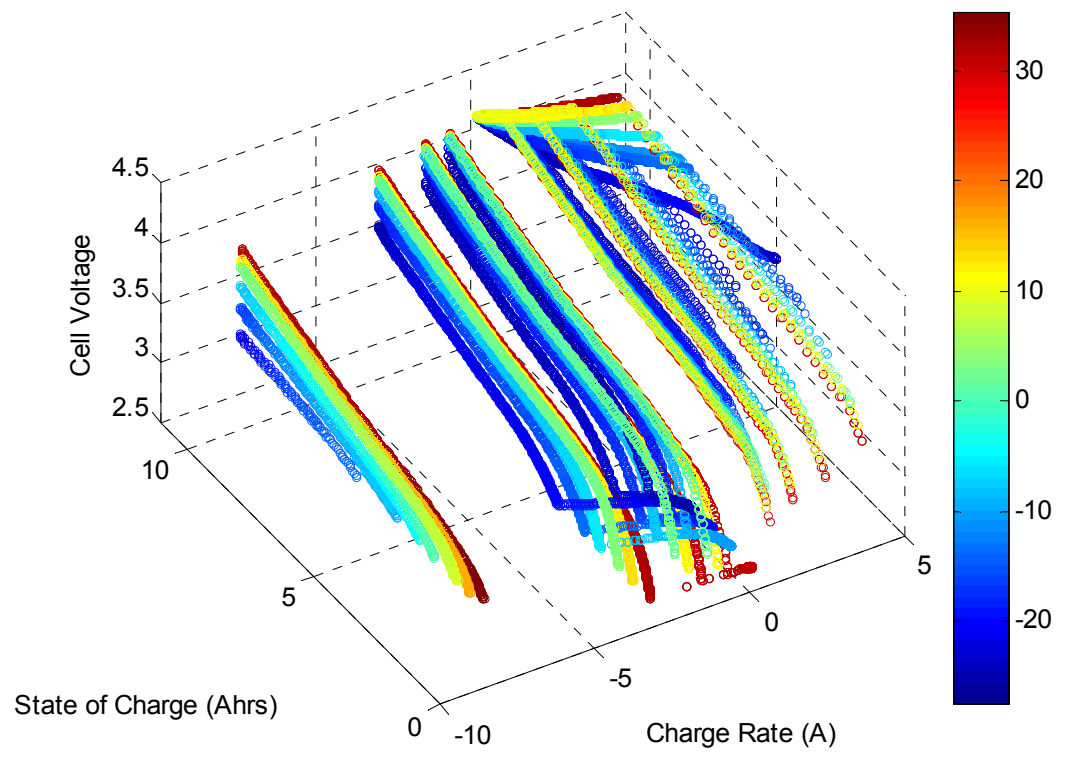

Figure 3.-MER Rover battery data. 
taper down to $\mathrm{C} / 100$ (1/100 times the battery capacity). Likewise, some discharge cycles had a taper discharge in which the voltage was held constant at $2.75 \mathrm{~V}$ at the end of the discharge, with the discharge rate allowed to taper. This tapered discharge provided valuable cell data at low discharge rates for the data reduction, and allowed subsequent charge cycles to begin with a lower state of charge.

For some test cycles, particularly for high rates at low temperatures, the cell temperature varied significantly during the run, as shown in figure 4, which shows an example for one discharge rate, with the test data points in blue, superimposed on a mesh surface fit derived from this data.

The surface shown in figure 4 was used to adjust the test data to compensate for the temperature variation during each cycle. The resulting temperature-compensated data was then used, along with the taper-charge data, to derive surfaces for voltage as a function of state of charge, current, and temperature. One example of these surfaces is shown in figure 5, with the test data superimposed in blue.

In contrast to MER's $10 \mathrm{~A}$-hr batteries, Orion has baselined $55 \mathrm{~A}-\mathrm{hr}$ batteries, so scaling is required. Scaling the current and state of charge according to the capacity ratio over-estimates the battery internal resistance, based on the comparison with data for the larger cells. However, with the internal resistance adjusted by an additional factor, the scaled battery model has an excellent comparison with measured cell data.

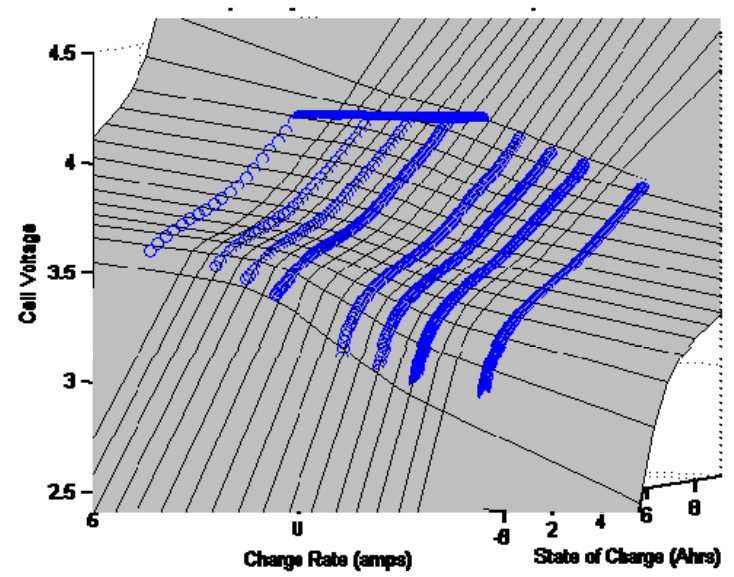

Figure 4.-Battery voltage model versus test data, temperature, $0^{\circ} \mathrm{C}$

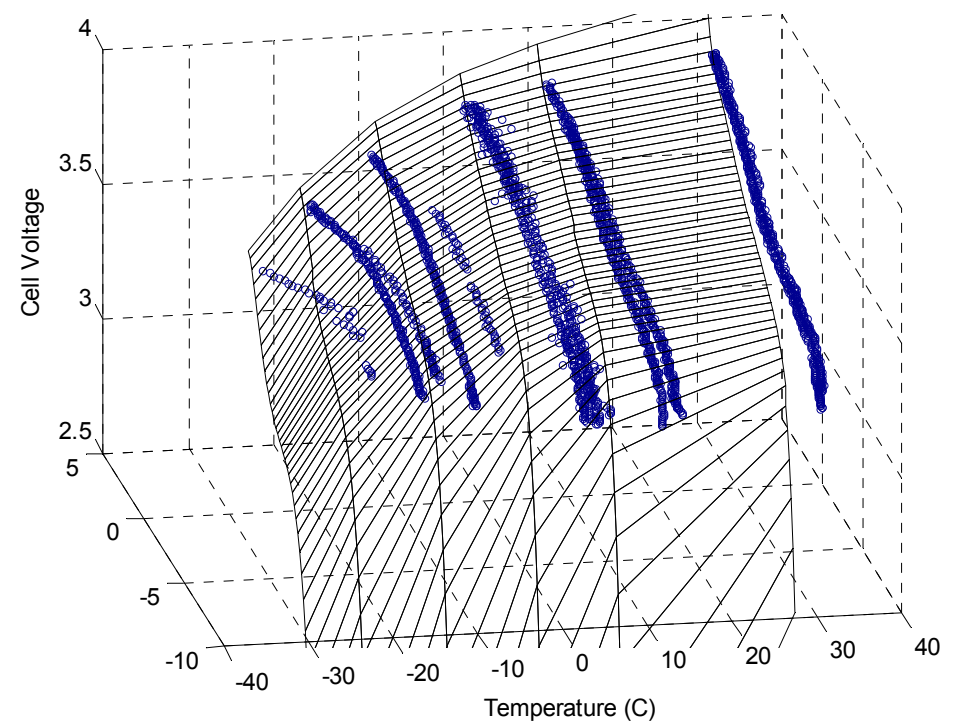

Figure 5.-Voltage as a function of state-of-charge and temperature for $8 \mathrm{~A}$ discharge. 


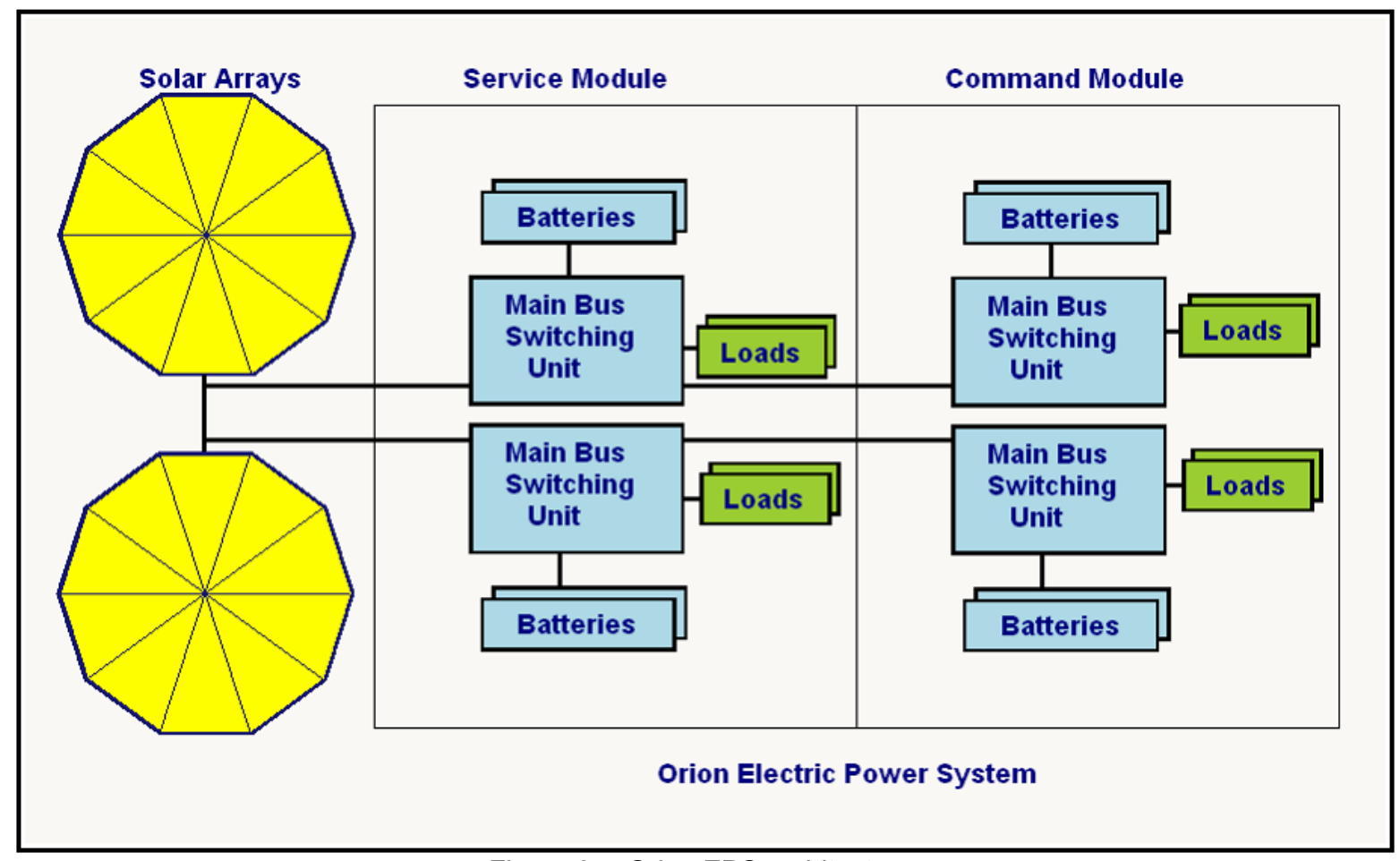

Figure 6.-Orion EPS architecture.

\section{Electrical System}

The Orion spacecraft has a Service Module (SM) and a Crew Module (CM). The primary electric system of the SM has two solar array wings (SAW), two Main Bus Switching Units (MBSU) and four batteries. The primary electric system of the CM contains two MBSUs and six batteries. Each MBSU has two separate bus bars. There are four umbilical cables feeding the CM MBSU bus bars from the SM MBSU bus bars. Connections for Ground Support Equipment (GSE), a Power Transfer Unit (PTU) and a docking system are provided. The primary systems feed secondary harnesses powering approximately 500 individual loads with a total load demand of $4 \mathrm{kWe}$. Thus the Orion electrical system is more than 10 times larger than the MER electric system, which has a load demand of $0.3 \mathrm{kWe}$; and 25 times smaller than the ISS, which has a load demand of $100 \mathrm{kWe}$. An overview of the Orion primary electric system is shown in figure 6.

\section{Model-to-Model Validation}

One common difficulty in utilizing models early in a spacecraft development cycle (e.g., prior to Preliminary Design Review) is that few actual test data are available with which to anchor model predictions. Therefore, significant uncertainty factors must be applied, prior to test data becoming available. One way to reduce that uncertainty is to compare the results of more than one independentlydeveloped model. Although that does not eliminate errors that might result from incorrect predictions of how a given component might perform, it does help ensure that, at the system level, the models are behaving correctly and incorporate all the important effects due to environments, operating conditions and lifetime. Note that this technique is only really valuable if the models are indeed independently developed, where different algorithmic choices might be made in solving for some critical parameters, and it is less likely that similar mistakes would be made in each model. If the models are not independently developed, there is somewhat greater risk that the models could have propagated a similar error that model-to-model comparisons will not find. Given that three independently-developed models are available for Orion this methodology was chosen to help validate the models' predictions. 


\section{Methodology and Cases}

The strategy adopted for validating the performance of the three models was to run them under identical conditions and compare the results. A modeling Technical Interchange Meeting (TIM) was held to obtain agreement on the values of the important modeling parameters. The results of that meeting were documented in a CEV Sizing Parameters spreadsheet, maintained by Glenn Research Center. These parameters included definitions of the environment conditions encountered by the CEV (e.g., radiation fluence, and albedo and infra-red fluxes); sizing and performance values for the solar arrays (e.g., solar cell performance and degradation factors) and batteries (current-voltage characteristics); the transmission network (cable lengths and gauges) and the electrical loads themselves.

A sample extracted from the CEV Sizing Parameters spreadsheet is shown in table II.

TABLE II.-EXCERPT FROM CASE PARAMETER MATRIX

\begin{tabular}{|l|c|c|c|}
\hline \multicolumn{3}{|c|}{ Environments } \\
\hline Description & Value & & Units \\
\hline Solar flux & LEO & LLO & \\
\hline Albedo & Min Flux & Min Flux & $\mathrm{W} / \mathrm{m}^{2}$ \\
\hline IR & & 0.135 & ------- \\
\hline Rad fluence (current)_-IAF & & Calc & $\mathrm{W} / \mathrm{m}^{2}$ \\
\hline Rad fluence (voltage)_-VAF & $5.888 \mathrm{E}+11$ & $4.261 \mathrm{E}+13$ & $\mathrm{no.} / \mathrm{cm}^{2}$-yr \\
\hline Mission length & $9.156 \mathrm{E}+11$ & $5.905 \mathrm{E}+13$ & $\mathrm{no} / \mathrm{cm}^{2}$-yr \\
\hline
\end{tabular}

Note that in many cases the parameters will differ between the LEO mission to the ISS, and the lunar mission, and therefore two sets of parameters must be maintained for each model.

Because of the numerous variables that must be calculated properly by a properly-functioning power system model, numerous different comparisons must be performed to exercise all features of the models. Therefore, the following list of cases was selected for comparison:

(1) Predictions of insolation/eclipse times for LLO and LEO orbits as a function of the solar beta angle ( $\beta$ )

(2) Solar array performance for LLO and LEO orbits for various $\beta$ s and insolation intensities

(3) Solar array shadowing patterns for LLO orbits, LEO orbits and for Orion docked at the ISS

(4) Solar array voltage, current, and temperature; battery voltage, current, SOC; and system losses for ISS and lunar mission scenarios.

(5) Solar array gimbal positions necessary to track the sun for LLO and LEO orbits for various $\beta \mathrm{s}$

(6) Battery voltage profiles for different charge/discharge conditions

\section{Summary Results of Comparisons}

Each of the three power system models was updated appropriately for the Orion EPS architecture and the appropriate orbital environments in LEO and LLO orbits. Each of the three models was then executed in turn, and the time-varying results were generated. Unfortunately each model produces its outputs in a slightly different format, at differing time intervals, so a simple direct comparison of results is not possible. Therefore, all the model results were imported into a large Microsoft Excel Workbook so they could be examined side-by-side. The timing of the results from each model was adjusted to synchronize them to a common time datum, and then the results were plotted for comparison. Initial comparisons showed some differences between the models, and modeling reviews identified the sources of the discrepancies so they could be corrected. Most of the differences were due to incorrect application of input data unique to the Orion mission. The results shown below are after correcting the input data errors. 


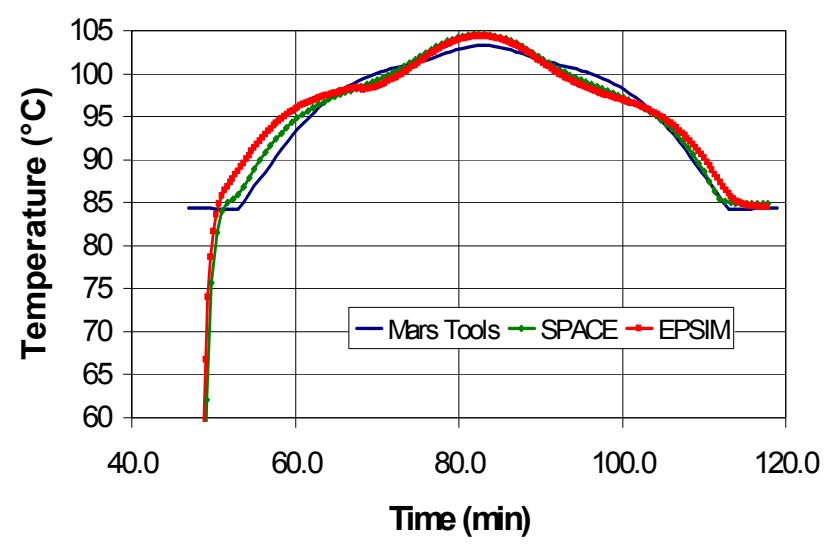

Figure 7.-Comparison of solar array wing temperatures in lunar orbit.

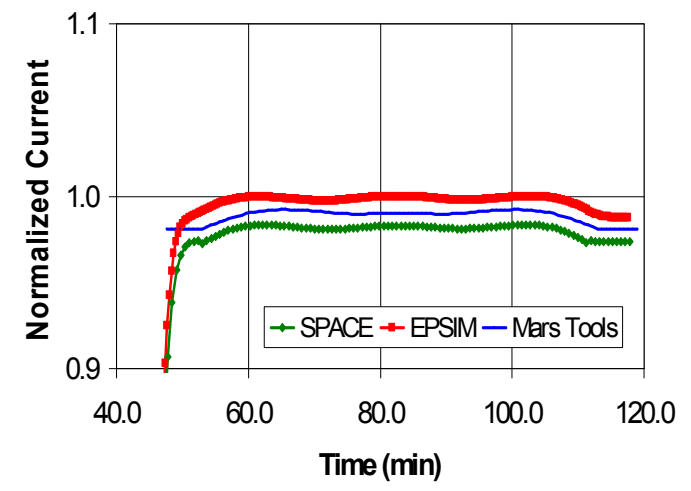

Figure 8.-Normalized maximum power current.

Solar array performance is the most critical parameter for Orion, since the solar arrays must generate all the energy that Orion systems will require throughout the mission. Therefore, a great deal of time was spent comparing solar array performance estimates. As mentioned above, the lunar thermal environment is a stressing environment for the solar array due to the high thermal fluxes from the lunar surface. Figure 7 shows how the temperature predictions compare among the three models for the hottest lunar case. The plot shows the temperature versus time for the insolation period of a single orbit, where the solar beta angle is $0^{\circ}$.

The three models all predict similar shapes for the temperature curves. SPACE predicts the highest temperature of $104.6^{\circ} \mathrm{C}$, and the maximum difference in peak temperature between the three models is only $1.3{ }^{\circ} \mathrm{C}$. The average temperature throughout the sun period is matched to within $0.1^{\circ} \mathrm{C}$ between EPSIM and SPACE, while the average temperature predicted by the Mars tools is approximately $3{ }^{\circ} \mathrm{C}$ higher. This larger discrepancy is because the Mars tools use an arithmetic, or steady-state, thermal model which does not capture the large temperature gradient at the beginning of insolation. The other two models use a transient thermal model which properly predicts that slope. This difference is not of concern because that time period is short and does not appreciably affect the overall energy production from the solar array. The slight difference between SPACE and EPSIM in the shape of the curves can be explained by different algorithms used to calculate the infra-red heat flux off the lunar surface. Despite the different algorithms used, the average and peak temperatures match within an expected error band. Given that the three independent models predict very similar temperatures, the Orion project can have confidence that solar array thermal performance is being properly modeled.

Figure 8 shows the current generated by the solar array wings at the peak power point. The results are presented in a normalized matter (where $1.0=$ maximum current predicted by any of the three models) because the precise solar array design and size was not available at the time this analysis was performed. 
As with temperature, all three models predict similar shaped curves. Peak current differences are less than 2 percent. Any difference in temperature between the models will translate to a corresponding difference in current, and so some of this 2 percent difference is due to the temperature models. The fact that the three curves are all offset from one another, in contrast to the temperature curves, which cross, indicates that there are some other systemic differences between the models. Those further differences are still being investigated, but have not been identified at the time of the writing of this paper. However, the fact that the difference is less than 2 percent is good evidence that all three models are predicting the current reasonably and have no large undetected errors.

Similar consistent comparisons were seen for voltage, further corroborating that the three models are behaving as expected. Cases were also run for other solar beta angles, and for LEO orbits as well, all of which show similar results. This confirms that the variation in orbital environments is correctly modeled in all three cases. Comparisons of battery performance predictions is future work which has not yet been completed.

\section{Conclusions}

By leveraging power system models developed for past programs such as the International Space Station and the Mars Exploration Program, the Constellation Program has been able to rapidly develop detailed power system modeling capabilities. Three such models are being utilized to help design and analyze the Orion power system. The extensive heritage of these models, increases confidence that the performance estimates are reasonable, and provides a means to obtain detailed analysis results at a very early stage in the spacecraft development.

Comparing the results of three independently-developed models provides one means of validating model prediction, prior to test data becoming available. Comparisons to date between the three models has yielded excellent agreement on solar array temperature and electrical performance predictions. Work continues comparing solar array shadowing and battery performance to help validate the complete power system model suite.

\section{References}

1. "Constellation Program Electrical Power System Specification-Volume 1: Electrical Power Quality Performance for 28VDC," CxP 70050-01, NASA Constellation Program, Level II, November 30, 2007.

2. Fincannon, J., "Characterization of Lunar Polar Illumination from a Power System Perspective," AIAA 20080447, 46th AIAA Aerospace Sciences Meeting, Reno, NV, January 7-10, 2008.

3. Hoffman, D.J., "Power System Architectures for NASA's Exploration Missions," Space Power Workshop, The Aerospace Corporation and Air Force Research Laboratory/SMC, Manhattan Beach, CA, April 22-24, 2008.

4. Hojnicki, J.S., Green, R.D., Kerslake, T.W., McKissock, D.B., and Trudell, J.J., "Space Station Freedom Electrical Performance Model," NASA TM-106395, 28th Intersociety Energy Conversion Engineering Conference, Atlanta, Georgia, August 8-13, 1993.

5. Jannette, A.G. et al., "Validation of International Space Station Electrical Performance Model Via On-Orbit Telemetry," NASA/TM-2002-211803, 37th Intersociety Energy Conversion Engineering Conference, Washington, D.C., July 28 to August 2, 2002.

6. Ayres, M., Wait, D.L., Le, T., and Wiederholt, M., "Simulation of Large Scale Spacecraft Power Systems Using Sparse-Matrix Solution Techniques," The $5^{\text {th }}$ NASA Symposium on Large-Scale Analysis, Design and Intelligent Syntheses Environments, NASA Langley Research Center, Hampton, VA, October 12-15 1999.

7. Jordan, C.E., "NASA radiation belt models AP-8 and AE-8," Report AD-A223660, Sep 30, 1989.

8. Marvin, D.C., "Assessment of Multijunction Solar Cell Performance in Radiation Environments," Aerospace Report No. TOR-2000(1210)-1, February 29, 2000. 
9. Heynderickx, D., Quaghebeur, B., and Evans, H.D.R., "The ESA Space Environment Information System (SPENVIS)," IAF abstracts, 34th COSPAR Scientific Assembly, The Second World Space Congress, Houston, TX, October, 10-19, 2002.

10. Katzan, C.M. et al., "The Effects of Lunar Dust Accumulation on the Performance of Photovoltaic Arrays," Space Photovoltaic Research and Technology Conference, Cleveland, Ohio, August 1, 1991.

11. Bugga, R. et al., "Lithium Ion Batteries on 2003 Mars Exploration Rover," NASA/CP-2003212344, The 2002 NASA Aerospace Battery Workshop, April 2003. 


\begin{tabular}{|c|c|c|}
\hline \multicolumn{2}{|c|}{ REPORT DOCUMENTATION PAGE } & $\begin{array}{c}\text { Form Approved } \\
\text { OMB No. 0704-0188 }\end{array}$ \\
\hline \multicolumn{3}{|c|}{ 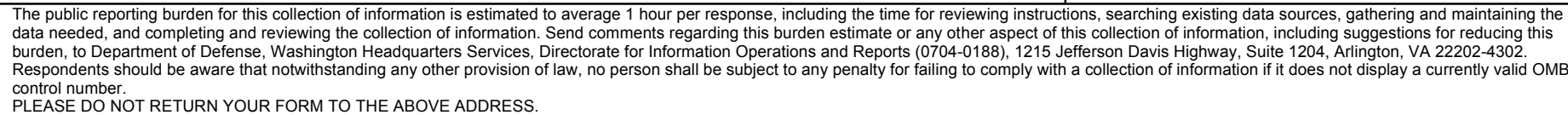 } \\
\hline $\begin{array}{l}\text { 1. REPORT DATE (DD-MM-YYYY) } \\
01-09-2008\end{array}$ & $\begin{array}{l}\text { 2. REPORT TYPE } \\
\text { Technical Memorandum }\end{array}$ & 3. DATES COVERED (From - To) \\
\hline \multirow{3}{*}{\multicolumn{2}{|c|}{$\begin{array}{l}\text { 4. TITLE AND SUBTITLE } \\
\text { Adaptation and Re-Use of Spacecraft Power System Models for the Constellation Program }\end{array}$}} & 5a. CONTRACT NUMBER \\
\hline & & 5b. GRANT NUMBER \\
\hline & & 5c. PROGRAM ELEMENT NUMBER \\
\hline \multirow{3}{*}{\multicolumn{2}{|c|}{$\begin{array}{l}\text { 6. AUTHOR(S) } \\
\text { Hojnicki, Jeffrey, S.; Kerslake, Thomas, W.; Ayres, Mark; Han, Augustina, H.; Adamson, } \\
\text { Adrian, M. }\end{array}$}} & 5d. PROJECT NUMBER \\
\hline & & 5e. TASK NUMBER \\
\hline & & $\begin{array}{l}\text { 5f. WORK UNIT NUMBER } \\
\text { WBS 644423.06.32.03.05.03 }\end{array}$ \\
\hline \multicolumn{2}{|c|}{$\begin{array}{l}\text { 7. PERFORMING ORGANIZATION NAME(S) AND ADDRESS(ES) } \\
\text { National Aeronautics and Space Administration } \\
\text { John H. Glenn Research Center at Lewis Field } \\
\text { Cleveland, Ohio 44135-3191 }\end{array}$} & $\begin{array}{l}\text { 8. PERFORMING ORGANIZATION } \\
\text { REPORT NUMBER } \\
\text { E-16594 }\end{array}$ \\
\hline \multirow{2}{*}{\multicolumn{2}{|c|}{$\begin{array}{l}\text { 9. SPONSORING/MONITORING AGENCY NAME(S) AND ADDRESS(ES) } \\
\text { National Aeronautics and Space Administration } \\
\text { Washington, DC 20546-0001 }\end{array}$}} & $\begin{array}{l}\text { 10. SPONSORING/MONITORS } \\
\text { ACRONYM(S) } \\
\text { NASA }\end{array}$ \\
\hline & & $\begin{array}{l}\text { 11. SPONSORING/MONITORING } \\
\text { REPORT NUMBER } \\
\text { NASA/TM-2008-215425; AIAA-2008- } \\
5616 \\
\end{array}$ \\
\hline \multicolumn{3}{|c|}{$\begin{array}{l}\text { 12. DISTRIBUTION/AVAILABILITY STATEMENT } \\
\text { Unclassified-Unlimited } \\
\text { Subject Category: } 20 \\
\text { Available electronically at http://gltrs.grc.nasa.gov } \\
\text { This publication is available from the NASA Center for AeroSpace Information, 301-621-0390 }\end{array}$} \\
\hline
\end{tabular}

\section{SUPPLEMENTARY NOTES}

\section{ABSTRACT}

NASA's Constellation Program is embarking on a new era of space exploration, returning to the Moon and beyond. The Constellation architecture will consist of a number of new spacecraft elements, including the Orion crew exploration vehicle, the Altair lunar lander, and the Ares family of launch vehicles. Each of these new spacecraft elements will need an electric power system, and those power systems will need to be designed to fulfill unique mission objectives and to survive the unique environments encountered on a lunar exploration mission. As with any new spacecraft power system development, preliminary design work will rely heavily on analysis to select the proper power technologies, size the power system components, and predict the system performance throughout the required mission profile. Constellation projects have the advantage of leveraging power system modeling developments from other recent programs such as the International Space Station (ISS) and the Mars Exploration Program. These programs have developed mature power system modeling tools, which can be quickly modified to meet the unique needs of Constellation, and thus provide a rapid capability for detailed power system modeling that otherwise would not exist.

\section{SUBJECT TERMS}

Constellation program; Crew Exploration Vehicle; Spacecraft power supplies; Solar arrays; Lithium batteries; Mathematical models

\begin{tabular}{|c|c|c|c|c|c|}
\hline \multicolumn{3}{|c|}{ 16. SECURITY CLASSIFICATION OF: } & \multirow{2}{*}{$\begin{array}{l}\text { 17. LIMITATION OF } \\
\text { ABSTRACT } \\
\text { UU }\end{array}$} & \multirow{2}{*}{$\begin{array}{l}\text { 18. NUMBER } \\
\text { OF } \\
\text { PAGES } \\
21\end{array}$} & \multirow{2}{*}{$\begin{array}{l}\text { 19a. NAME OF RESPONSIBLE PERSON } \\
\text { STI Help Desk (email:help@sti.nasa.gov) } \\
\text { 19b. TELEPHONE NUMBER (include area code) } \\
\text { 301-621-0390 }\end{array}$} \\
\hline $\begin{array}{l}\text { a. REPORT } \\
U\end{array}$ & $\begin{array}{l}\text { b. ABSTRACT } \\
U\end{array}$ & $\begin{array}{l}\text { c. THIS } \\
\text { PAGE } \\
\text { U }\end{array}$ & & & \\
\hline
\end{tabular}



